\title{
Penyebaran Limbah Air Panas PLTU Di Kolam Pelabuhan Semarang
}

\author{
Petrus Subardjo dan Raden Ario* \\ Jurusan IImu Kelautan, Fakultas Perikanan dan Ilmu Kelautan, Universitas Diponegoro \\ JI. Prof. Soedarto, SH. Kampus UNDIP Tembalang, Semarang 50275 \\ Email:ario_1960@yahoo.com
}

\begin{abstract}
Abstrak
Kolam Pelabuhan Tambak Lorok Semarang yang terletak di pantai utara Pulau Jawa telah mengalami perkembangan yang cukup pesat dalam menunjang aktivitas bidang industri. Pembangkit Listrik Tenaga Uap (PLTU) Tambak Lorok merupakan salah satu industri yang membuang limbah panas ke perairan sekitarnya. Pembuangan limbah air panas ini berpengaruh langsung terhadap suhu lingkungan perairan. Penelitian yang dilaksanakan pada bulan Agustus - Oktober 2012 ini bertujuan untuk mengetahui pola sebaran panas akibat limbah panas dari PLTU di Kolam Pelabuhan Tambak Lorok Semarang. Metode samplng purposif dilakukan dengan menetapkan sejumlah stasiun dengan pertimbangan yang ditetapkan berdasarkan tujuan penelitian. Pengambilan sampel dilakukan di delapan titik lokasi penelitian dengan pengumpulan data berupa suhu yang merupakan variabel kontrol. Data sebaran suhu dari kanal pendingin yang diperoleh selanjutnya dianalisis menggunakan program Surface Water Modeling System (SMS) sehingga menghasilkan peta sebaran panas. Hasil pemetaan sebaran menunjukkan bahwa pola sebaran panas di Kolam Pelabuhan Tambak Lorok Semarang menuju ke arah timur pada bulan Agustus 2012, kemudian ke arah barat laut di bulan September 2012, dan ke arah timur laut pada bulan Oktober 2012. Pola sebaran panas paling tinggi hanya terjadi pada daerah outlet dan semakin turun ketika menjauhi outlet karena pengaruh arus dan semakin bertambahnya kedalaman perairan.
\end{abstract}

Kata kunci: Limbah, Panas, PLTU, Pelabuhan

\section{PENDAHULUAN}

Perkembangan industri memberikan dua keadaan yang saling bertolak belakang, di satu sisi memberikan keuntungan secara ekonomi dan disisi lain meningkatkan konsentrasi pencemaran yang berasal dari hasil buangan tersebut. Bila peningkatan industri tidak diikuti dengan pengelolaan lingkungan yang baik maka peningkatan konsentrasi buangan limbah industri akan menimbulkan pengaruh yang buruk terhadap kualitas lingkungan (Mihardja, 1999).

Salah satu buangan industri yang berbahaya adalah limbah panas. Tambak Lorok yang terletak di pantai utara JawaTengah telah mengalami perkembangan yang cukup pesat dalam bidang industri. Salah satu industri yang ada di Tambak Lorok adalah Pembangkit Listrik Tenaga Uap (PLTU) Tambak Lorok.
Pembuangan air limbah PLTU secara langsung ke badan air sekitarnya tanpa melalui proses pendinginan kembali dapat menyebabkan perubahan kuantitas perairan maupun pengaruh terhadap organisme yang hidup dalam badan air (Huboyo dan Badrus, 2007). Kelebihan panas akan merubah ambien suhu air dan dapat mempegaruhi ekosistem akuatik baik secara langsung maupun tidak langsung (Fuad dan Arif, 2003). Sementara llahude (1995) juga menyebutkan bahwa organisme laut dapat hidup, tumbuh dan berkembang dalam batasan suhu tertentu. Perubahan suhu kemungkinan juga dapat mempengaruhi salinitas baik terhadap air limbah pendingin sendiri maupun perairan sepanjang penyebaran air limbah tersebut karena adanya proses percampuran antara air limbah dengan badan air di titik pembuangan dan sekitarnya. 
Melihat kondisi tersebut perlu adanya suatu penelitian mengenai sebaran suhu buangan air limbah tersebut sebagai salah satu cara monitoring kondisi Lingkungan (Huboyo dan Badrus, 2007). Untuk mengetahui sebaran air limbah ke badan air sekitarnya tersebut perlu adanya suatu sistem yang informatif karena berdasarkan penelitian-penelitian yang ada pada umumnya hanya memberikan database yang kadang kurang memberikan kemudahan untuk dipahami dengan baik dan kurang informatif padahal informasi tersebut sangat diperlukan untuk program mengenai kualitas lingkungan dimasa datang (Burhanuddin dan Martosewojo, S. 1989). Sistem yang informatif akan memberi kemudahan dalam analisis kondisi lingkungan yang terjadi khususnya mengenai kondisi penyebaran limbah air panas dan kemungkinan perubahan salinitasnya.

Pembangunan PLTU membutuhkan air laut untuk pendingin kondensor yang menghasilkan panas kemudian dibuang di perairan di sekitanya. Pembuangan limbah sebagai pendingin akan mempengaruhi kondisi lingkungan disekitarnya akan menimbulkan pencampuran air panas diantaranya akibat gelombang, arus, pasang surut. Pada Studi ini limbah air panas tersebut akan disusun menjadi pola sebaran panas dengan menggunakan pendekatan model numerik. Pendekatan model numerik digunakan dalam penelitian ini karena merupakan salah satu cara pemantauan yang lebih efisien dilihat dari aspek tenaga, biaya dan waktu.

\section{MATERI DAN METODE}

Materi yang digunakan dalam penelitian ini adalah data primer dan data sekunder. Data primer yang digunakan sebagai kajian penelitian suhu permukaan laut dari pendingin PLTU yang menggunakan air laut. Data pengambilan sampel di lapangan dilakukan selama bulan Agustus - Oktober 2012. Data sekunder meliputi data Suhu perairan dari Stasiun Meteorologi Maritim, Badan Meteorologi Klimatologi dan Geofisika (BMKG) Kota Semarang. Penentuan delapan lokasi stasiun penelitian dilakukan berdasarkan kondisi secara keseluruhan daerah perairan laut disekitar lokasi outlet PLTU Semarang.

Alat dan bahan yang digunakan dalam penelitian ini meliputi alat ukur suhu air laut dengan Water Quality Monitoring, GPS (Global Positioning System), dan data sekunder serta pengolahannya.

Metode yang digunakan dalam penelitian ini adalah pemodelan sebaran suhu dari saluran pendingin dilakukan dengan menggunakan perangkat lunak Surface Water Modeling System (SMS). Perangkat lunak SMS dapat digunakan untuk mengolah, mengedit dan memvisualisasikan data geometris dan hidrolika, baik untuk satu, dua maupun tiga dimensi.

Surface Water Modeling System memiliki berbagai modul berupa modelmodel numerik untuk berbagai keperluan. Modul-modul tersebut diantaranya adalah RMA2, RMA4, SED2D-WES, dan CGWAVE yang dikembangkan oleh Engineers Research and Development Center, HEC RAS yang dikembangkan oleh Hydrologic Engineering Center, serta FESWMS-Flo2DH yang dikembangkan oleh US Federal Highway Administration.

Data arah dan kecepatan arus hasil penghitungan RMA2 digunakan untuk membuat model pola sebaran suhu air hangat saluran pendingin dengan menggunakan modul RMA4. RMA4 adalah model numerik elemen hingga untuk transpot kualitas air, dimana distribusi konsentrasi terhadap kedalaman diasumsikan seragam. RMA4 tidak memperhitungkan satuan konsentrasi, karena konsentrasi yang dihitung adalah konsentrasi relatif terhadap konsentrasi awal yang telah ditentukan. Hasil pemodelan tersebut akan disajikan dalam SIG (Sistem Informasi Geografis) menggunakan software SIG yaitu ArcGIS.

Metode pengambilan data suhu dilakukan dengan menggunakan alat Water Quality Monitoring yang mempu mengukur suhu permukaan. Data suhu diukur mulai dari outlet PLTU yaitu pipa saluran pembuangan air panas dan 


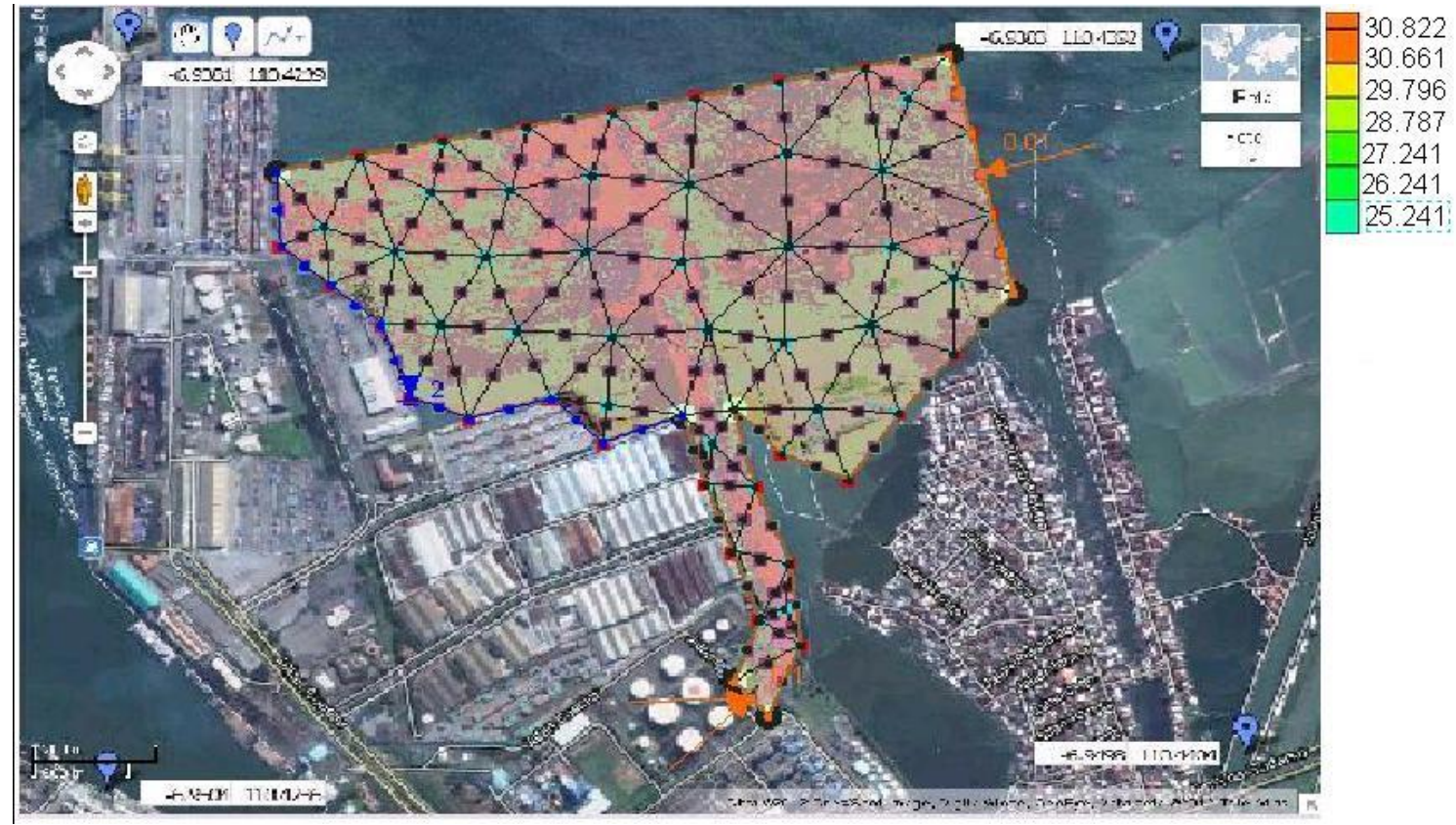

Gambar 1. Peta Mesh Daerah Model Pelabuhan Tambak Lorok Semarang

penyebaran pada kolam pelabuhan. Sedangkan data arus pada bulan Agustus Oktober 2012 diperoleh dari data pengukuran BMKG Pelabuhan Semarang.

Metode analisis data pola sebaran panas pada daerah penelitian didapat dari pengolahan dengan menggunakan software Surface Modeling System (SMS). Data yang dihasilkan yaitu kecepatan arus, suhu permukaan dan pola sebarannya. Arah sebaran panas mengikuti arah dan kecepatan arus. Pola yang ditampilkan adalah pola sebaran panas dan pola arus. Pola sebaran panas ditampilkan pada suhu permukaan rata-rata dan arus rata-rata pada bulan Agustus 2012 - Oktober 2012, kemudian hasil akan disajikan dengan SIG melalui peta yang dibuat menggunakan ArcGIS.

Proses Pemodelan Dengan Surface Modeling System (SMS) meliputi Input Data, Penentuan Kondisi Batas dan Kondisi Awal, Sifat Bahan, Analisis Sensitivitas, dan Validasi Model.

Proses pembuatan Peta dengan menggunakan ArcGIS perlu diperhatikan beberapa ketentuan, seperti ketelitian, konsentrasi, dan data yang akan diolah. Data dasar yang akan diolah menjadi peta ialah hasil pemodelan menggunakan software SMS yang berupa data penyebaran suhu di perairan kolam pelabuhan Tambak Lorok dari bulan Agustus 2012 hingga Oktober 2012 dan gabungan dari ketiga bulan tersebut yang dipengaruhi oleh pergerakan arus di perairan tersebut.

\section{HASIL DAN PEMBAHASAN}

Daerah Kolam Pelabuhan Tambak Lorok selvas 17.800 ha dengan kedalaman sekitar 1-10 m berada di KelurahanTanjung Mas Kecamatan Semarang Utara. Pemanfaatan lokasi di sekitar daerah penelitian dipergunakan untuk daerah pelabuhan, industri, tambak dan pemukiman. Data suhu dari pengukuran di lapangan dapat diketahui bahwa suhu tertinggi yaitu $31^{\circ} \mathrm{C}$ di bulan September dan Oktober pada pipa pembuangan hasil pendinginan PLTU dan suhu terendah yaitu $25^{\circ} \mathrm{C}$ pada bulan Agustus 2012 pada daerah titik jembatan outlet. Nilai suhu bervariasi pada tiap stasiun karena adanya perbedaan kedalaman.

Pola sebaran panas yang di overlay dengan arah dan kecepatan arus pada bulan Agustus 2012 menujukan 
pergerakan ke arah timur. Hal ini diakibatkan arus yang membawa massa panas bergerak ke arah timur. Suhu tertinggi pada bulan Agustus 2012 berkisar $30.3^{\circ} \mathrm{C}$ dengan suhu terendah $25.1^{\circ} \mathrm{C}$.

Pola sebaran panas yang di overlay dengan arah dan kecepatan arus pada bulan September 2012 menunjukan pergerakan ke arah barat sehingga melewati celah antara dua breakwater. Suhu tertinggi bulan September 2014 berkisar $30.94{ }^{\circ} \mathrm{C}$ dengan suhu terendah $25.1^{\circ} \mathrm{C}$

Pola sebaran panas yang di overlay dengan arah dan kecepatan arus pada bulan Oktober 2012 menunjukan pergerakan ke arah Timur laut sehingga melewati celah antara dua breakwater. Hal ini diakibatkan aliran air (arus) yang membawa massa panas bergerak ke arah barat. Suhu tertinggi bulan Oktober 2012 berkisar $30.94{ }^{\circ} \mathrm{C}$ dengan suhu terendah $26.41^{\circ} \mathrm{C}$

Untuk mengetahui kehandalan model dilakukan verifikasi hasil simulasi model dengan data lapangan. Verifikasi dilakukan secara kuantitatif yaitu dengan membandingkan pola grafik hasil perhitungan model dengan hasil dari lapangan (Gambar 2)

Setelah dilakukan penelitian di daerah Tambak Lorok mulai Agustus 2012 -
Oktober 2012 diperoleh data suhu pada setiap bulannya. Data suhu yang diperoleh dapat digambarkan pola penyebaranya melalui keadaan arus yang terjadi disekitar wilayah Tambak Lorok. Suhu rata-rata permukaan air laut Tambak Lorok pada bulan Agustus 2012 sekitar $28^{\circ} \mathrm{C}$ pada 8 (delapan) titik yang tersebar. Arah dan kecepatan arusnya dominan bergerak ke arah timur dengan kecepatan rata-rata 16 $\mathrm{m} / \mathrm{s}$., Keadaan suhu rata-rata permukaan air laut Tambak Lorok pada bulan September 2012 sekitar $29^{\circ} \mathrm{C}$. Arus dominan bergerak ke arah barat laut dengan kecepatan rata-rata $17 \mathrm{~m} / \mathrm{s}$. Sementara di bulan Oktober 2012 suhu rata-rata permukaan air laut Tambak Lorok bernilai $29^{\circ} \mathrm{C}$. Pergerakan arus dominan bergerak ke arah timur laut dengan kecepatan ratarata $13 \mathrm{~m} / \mathrm{s}$.

Pergerakan arus yang terjadi di sepanjang bulan Agustus 2012 hingga Oktober 2012 terlihat adanya perubahan gerakan di setiap bulannya. Adanya perbedaan arah tentunya dipengaruhi oleh keadaan angin dan arus yang terjadi pada setiap bulannya.

Hasil yang ada dapat di simpulkan bahwa pada bulan Agustus 2012 hingga Oktober 2012 sedang terjadi perubahan musim (pancaroba). Arah arus yang dipengaruhi oleh angin semula menuju ke timur pada bulan Agustus 2012, kemudian ke arah barat laut di bulan September, dan

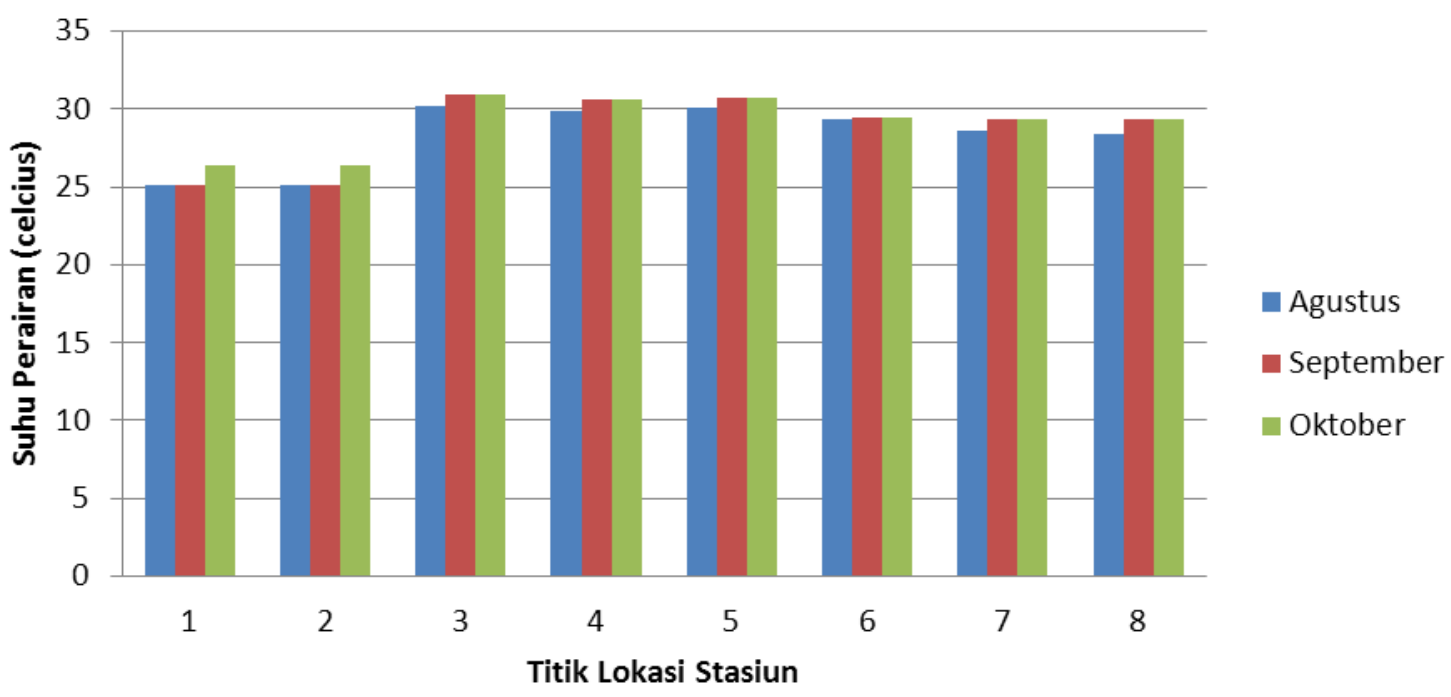

Gambar 2. Grafik Verifikasi Model terhadap Data Lapangan 
Tabel 1. Data Suhu Permukaan pada bulan Agustus` 2012

\begin{tabular}{|c|c|c|c|c|c|c|c|c|c|c|c|c|}
\hline \multicolumn{13}{|c|}{ AGUSTUS } \\
\hline$S$ & $E$ & KETERANGAN & ELEVASI & & & $x$ & & & & $y$ & & temperatur (celcius) \\
\hline $06^{\circ} 56^{\prime} 35.8^{\prime \prime}$ & $110^{\circ} 26^{\prime} 11.3^{\prime \prime}$ & Titik1 & 13 & 110 & 26 & 11.3 & 110.4364722 & 6 & 56 & 35.8 & -6.943277778 & - \\
\hline $06^{\circ} 56^{\prime} 36.3^{\prime \prime}$ & $110^{\circ} 26^{\prime} 9.4^{\prime \prime}$ & Titik2 & 10 & 110 & 26 & 9.4 & 110.4359444 & 6 & 56 & 36.3 & -6.943416667 & - \\
\hline $06^{\circ} 56^{\prime} 49.8^{\prime \prime}$ & $110^{\circ} 26^{\prime} 3.2^{\prime \prime}$ & Titik3 (Jembatan I) & 22 & 110 & 26 & 3.2 & 110.4342222 & 6 & 56 & 49.8 & -6.947166667 & 25.1 \\
\hline $06^{\circ} 56^{\prime} 50.1^{\prime \prime}$ & $110^{\circ} 26^{\prime} 2.6^{\prime \prime}$ & Titik 4 (Jembatan II) & 22 & 110 & 26 & 2.6 & 110.4340556 & 6 & 56 & 50.1 & -6.94725 & 25.1 \\
\hline $06^{\circ} 56^{\prime} 53.1^{\prime \prime}$ & $110^{\circ} 26^{\prime} 1.4^{\prime \prime}$ & Titik 5(PIPA) & 20 & 110 & 26 & 1.4 & 110.4337222 & 6 & 56 & 53.1 & -6.948083333 & 30.21 \\
\hline $06^{\circ} 56^{\prime} 54.8^{\prime \prime}$ & $110^{\circ} 26^{\prime} 0.1^{\prime \prime}$ & Titik6(titik outlet) & 22 & 110 & 26 & 0.1 & 110.4333611 & 6 & 56 & 54.8 & -6.948555556 & 29.87 \\
\hline $06^{\circ} 56^{\prime} 56.9^{\prime \prime}$ & $110^{\circ} 25^{\prime} 59.7^{\prime \prime}$ & Titik 7 (OUTLET UTAMA) & 22 & 110 & 25 & 59.7 & 110.43325 & 6 & 56 & 56.9 & -6.949138889 & 30.03 \\
\hline $06^{\circ} 56^{\prime} 57.9^{\prime \prime}$ & $110^{\circ} 26^{\prime} 2.0^{\prime \prime}$ & Titik 8(Penyebaran II) & 18 & 110 & 26 & 2 & 110.4338889 & 6 & 56 & 57.9 & -6.949416667 & 29.34 \\
\hline $06^{\circ} 56^{\prime} 48.4^{\prime \prime}$ & $110^{\circ} 26^{\prime} 1.3^{\prime \prime}$ & Titik 9(Penyebaran III) & 22 & 110 & 26 & 1.3 & 110.4336944 & 6 & 56 & 48.4 & -6.946777778 & 28.563 \\
\hline $06^{\circ} 56^{\prime} 45.9^{\prime \prime}$ & $110^{\circ} 26^{\prime} 0.4^{\prime \prime}$ & Titik 10 (Penyebaran IV) & 17 & 110 & 26 & 0.4 & 110.4334444 & 6 & 56 & 45.9 & -6.946083333 & 28.43 \\
\hline $06^{\circ} 56^{\prime} 55.0^{\prime \prime}$ & $110^{\circ} 25^{\prime} 11.2^{\prime \prime}$ & Titik11(BMKG) & 17 & 110 & 25 & 11.2 & 110.4197778 & 6 & 56 & 55 & -6.948611111 & - \\
\hline
\end{tabular}

Tabel 2. Data Suhu Permukaan pada bulan September 2012

\begin{tabular}{|c|c|c|c|c|c|c|c|c|c|c|c|c|}
\hline \multicolumn{13}{|c|}{ SEPTEMBER } \\
\hline$S$ & $E$ & KETERANGAN & ELEVASI & & & $x$ & & & & $y$ & & temperatur (celciuss \\
\hline $06^{\circ} 56^{\prime} 35.8^{\prime \prime}$ & $110^{\circ} 26^{\prime} 11.3^{\prime \prime}$ & Titik1 & 13 & 110 & 26 & 11.3 & 110.4364722 & 6 & 56 & 35.8 & -6.943277778 & - \\
\hline $06^{\circ} 56^{\prime} 36.3^{\prime \prime}$ & $110^{\circ} 26^{\prime} 9.4^{\prime \prime}$ & Titik2 & 10 & 110 & 26 & 9.4 & 110.4359444 & 6 & 56 & 36.3 & -6.943416667 & - \\
\hline $06^{\circ} 56^{\prime} 49.8^{\prime \prime}$ & $110^{\circ} 26^{\prime} 3.2^{\prime \prime}$ & Titik3(Jembatan I) & 22 & 110 & 26 & 3.2 & 110.4342222 & 6 & 56 & 49.8 & -6.947166667 & 25.1 \\
\hline $06^{\circ} 56^{\prime} 50.1^{\prime \prime}$ & $110^{\circ} 26^{\prime} 2.6^{\prime \prime}$ & Titik4 (Jembatan II) & 22 & 110 & 26 & 2.6 & 110.4340556 & 6 & 56 & 50.1 & -6.94725 & 25.1 \\
\hline $06^{\circ} 56^{\prime} 53.1^{\prime \prime}$ & $110^{\circ} 26^{\prime} 1.4^{\prime \prime}$ & Titik5(PIPA) & 20 & 110 & 26 & 1.4 & 110.4337222 & 6 & 56 & 53.1 & -6.948083333 & 30.94 \\
\hline $06^{\circ} 56^{\prime} 54.8^{\prime \prime}$ & $110^{\circ} 26^{\prime} 0.1^{\prime \prime}$ & Titik6(titik outlet) & 22 & 110 & 26 & 0.1 & 110.4333611 & 6 & 56 & 54.8 & -6.948555556 & 30.62 \\
\hline $06^{\circ} 56^{\prime} 56.9^{\prime \prime}$ & $110^{\circ} 25^{\prime} 59.7^{\prime \prime}$ & Titik7(OUTLET UTAMA) & 22 & 110 & 25 & 59.7 & 110.43325 & 6 & 56 & 56.9 & -6.949138889 & 30.71 \\
\hline $06^{\circ} 56^{\prime} 57.9^{\prime \prime}$ & $110^{\circ} 26^{\prime} 2.0^{\prime \prime}$ & Titik8(Penyebaran II) & 18 & 110 & 26 & 2 & 110.4338889 & 6 & 56 & 57.9 & -6.949416667 & 29.45 \\
\hline $06^{\circ} 56^{\prime} 48.4^{\prime \prime}$ & $110^{\circ} 26^{\prime} 1.3^{\prime \prime}$ & Titik9(Penyebaran III) & 22 & 110 & 26 & 1.3 & 110.4336944 & 6 & 56 & 48.4 & -6.946777778 & 29.37 \\
\hline $06^{\circ} 56^{\prime} 45.9^{\prime \prime}$ & $110^{\circ} 26^{\prime} 0.4^{\prime \prime}$ & Titik 10(Penyebaran IV) & 17 & 110 & 26 & 0.4 & 110.4334444 & 6 & 56 & 45.9 & -6.946083333 & 29.31 \\
\hline $06^{\circ} 56^{\prime} 55.0^{\prime \prime}$ & $110^{\circ} 25^{\prime} 11.2^{\prime \prime}$ & Titik11(BMKG) & 17 & 110 & 25 & 11.2 & 110.4197778 & 6 & 56 & 55 & -6.948611111 & - \\
\hline
\end{tabular}

Tabel 3. Data Suhu Permukaan pada bulan Oktober 2012

\begin{tabular}{|c|c|c|c|c|c|c|c|c|c|c|c|c|}
\hline \multicolumn{13}{|c|}{ OKTOBER } \\
\hline$S$ & $E$ & KETERANGAN & ELEVASI & \multicolumn{4}{|c|}{$x$} & \multicolumn{4}{|c|}{$y$} & \multirow{2}{*}{$\begin{array}{c}\text { temperatur (celcius) } \\
-\end{array}$} \\
\hline $06^{\circ} 56^{\prime} 35.8^{\prime \prime}$ & $110^{\circ} 26^{\prime} 11.3^{\prime \prime}$ & Titik1 & 13 & 110 & 26 & 11.3 & 110.4364722 & 6 & 56 & 35.8 & -6.943277778 & \\
\hline $06^{\circ} 56^{\prime} 36.3^{\prime \prime}$ & $110^{\circ} 26^{\prime} 9.4^{\prime \prime}$ & Titik2 & 10 & 110 & 26 & 9.4 & 110.4359444 & 6 & 56 & 36.3 & -6.943416667 & - \\
\hline $06^{\circ} 56^{\prime} 49.8^{\prime \prime}$ & $110^{\circ} 26^{\prime} 3.2^{\prime \prime}$ & Titik3(Jembatan I) & 22 & 110 & 26 & 3.2 & 110.4342222 & 6 & 56 & 49.8 & -6.947166667 & 26.41 \\
\hline $06^{\circ} 56^{\prime} 50.1^{\prime \prime}$ & $110^{\circ} 26^{\prime} 2.6^{\prime \prime}$ & Titik 4 (Jembatan II) & 22 & 110 & 26 & 2.6 & 110.4340556 & 6 & 56 & 50.1 & -6.94725 & 26.41 \\
\hline $06^{\circ} 56^{\prime} 53.1^{\prime \prime}$ & $110^{\circ} 26^{\prime} 1.4^{\prime \prime}$ & Titik5(PIPA) & 20 & 110 & 26 & 1.4 & 110.4337222 & 6 & 56 & 53.1 & -6.948083333 & 30.94 \\
\hline $06^{\circ} 56^{\prime} 54.8^{\prime \prime}$ & $110^{\circ} 26^{\prime} 0.1^{\prime \prime}$ & Titik6(titik outlet) & 22 & 110 & 26 & 0.1 & 110.4333611 & 6 & 56 & 54.8 & -6.948555556 & 30.62 \\
\hline $06^{\circ} 56^{\prime} 56.9^{\prime \prime}$ & $110^{\circ} 25^{\prime} 59.7^{11}$ & Titik7(OUTLET UTAMA) & 22 & 110 & 25 & 59.7 & 110.43325 & 6 & 56 & 56.9 & \begin{tabular}{|l|}
-6.949138889 \\
\end{tabular} & 30.71 \\
\hline $06^{\circ} 56^{\prime} 57.9^{\prime \prime}$ & $110^{\circ} 26^{\prime} 2.0^{\prime \prime}$ & Titik 8(Penyebaran II) & 18 & 110 & 26 & 2 & 110.4338889 & 6 & 56 & 57.9 & -6.949416667 & 29.45 \\
\hline $06^{\circ} 56^{\prime} 48.4^{\prime \prime}$ & $110^{\circ} 26^{\prime} 1.3^{\prime \prime}$ & Titik9(Penyebaran III) & 22 & 110 & 26 & 1.3 & 110.4336944 & 6 & 56 & 48.4 & -6.946777778 & 29.37 \\
\hline $06^{\circ} 56^{\prime} 45.9^{\prime \prime}$ & $110^{\circ} 26^{\prime} 0.4^{\prime \prime}$ & Titik 10 (Penyebaran IV) & 17 & 110 & 26 & 0.4 & 110.4334444 & 6 & 56 & 45.9 & -6.946083333 & 29.31 \\
\hline $06^{\circ} 56^{\prime} 55.0^{\prime \prime}$ & $110^{\circ} 25^{\prime} 11.2^{\prime \prime}$ & Titik11(BMKG) & 17 & 110 & 25 & 11.2 & 110.4197778 & 6 & 56 & 55 & -6.948611111 & - \\
\hline
\end{tabular}

ke arah timur laut pada bulan Oktober 2012. Secara tidak langsung sebaran panas kanal PLTU mengikuti arah arus yang ada, dimana sedang terjadi proses perubahan musim dari kemarau ke musim penghujan. Proses perubahan musim dan sebaran 
panas dari kanal PLTU ini dapat berdampak pada ekosistem ikan yang ada serta hasil tangkapan ikan bagi nelayan. Penyajian hasil pemodelan penyebaran panas secara SIG dengan pembuatan peta memudahkan untuk menganalisanya. Dengan kata lain, pada penelitian ini SIG berfungsi sebagai fasilitator ataupun sebagai media yang mendukung keabsahan penyajian hasil pengolahan dan pemodelan suatu data.

\section{KESIMPULAN}

Berdasarkan hasil penelitian dapat disimpulkan bahwa pola sebaran panas di Kolam Pelabuhan Tambak Lorok Semarang menuju ke arah timur pada bulan Agustus 2012, kemudian ke arah barat laut di bulan September 2012, dan ke arah timur laut pada bulan Oktober 2012. Pola sebaran panas paling tinggi hanya terjadi pada daerah outlet dan semakin turun ketika menjauhi outlet karena pengaruh arus dan semakin bertambahnya kedalaman perairan. Sebaran panas di daerah penelitian dipngaruhi oleh arus, kedalaman perairan dan arah angin yang menggerakkan arus.

\section{UCAPAN TERIMA KASIH}

Ucapan terima kasih atas bantuan dan kerja-samanya kepada Afriza Aziz yang telah membantu dalam pelaksanaan penelitian hingga penulisan ini.

\section{DAFTAR PUSTAKA}

Burhanuddin dan Martosewojo, S. 1989. Limbah termal dan pengaruhnya terhadap keberadaan ikan di PLTU Muara Karang. Prosiding Seminar Ekologi Laut dan Pesisir I, Jakarta.
Dishidros TNI AL. 2007. Peta Batimetri Jawa Pantai Utara, Semarang sampai Tanjung Awar-awar. Jakarta.

Environmental Modeling Research Laboratory. 2006. The Surface Water Modeling System (SMS) - version 9.2 Tutorials.

Fuad, M dan Arif $Z$, 2003. Pola Penyebaran Air Limbah PLTU Tambak Lorok Semarang, Praktek Kerja Lapangan Jurusan IImU Kelautan FPIK Undip.

Huboyo, H. S. dan Badrus, Z. 2007. Analisis Sebaran Temperatur dan Salinitas Air Limbah PLTU-PLTGU Berdasarkan Sistem Pemetaan Spasial (Studi Kasus: PLTU-PLTGU Tambak Lorok Semarang), Jurnal Presipitasi, Vol. 3, No. 2, September 2007. Semarang.

Ismanto, A., Widada, S., dan Susiati, H. 2008. Kajian Dispersi Termal dalam Rencana Pembangunan PLTN Muria: Sebuah Analisis, Jurnal Geoaplika, Vol. 3, No. 3, 2008.

llahude, 1999. Pengantar ke Oseanologi Fisika. LIPI. Jakarta

Kennish, M. J. 2001. Practical Handbook of Marine Science. Third Edition. New Jersey : Institute of Marine and Coastal Sciences, Rutgers University.

King, I. 1996. Users Guide to RMA2 WES Version 4.3. Edited by Donnel, B. P. 1997. New York: US Army Corps of Engineer Waterways Experiment Station, Hydraulics Laboratory, Wex Tech System.

King, I. 2003. Users Guide to RMA4 WES Version 4.3. Edited by Donnel, B. P. 2003. New York: US Army, Engineer and Development Center - Waterways Experiment Station, Coastal and Hydraulics Laboratory, Wex Tech System.

Mihardja, D. K., 1999. Modelling of the Heated Water Spreading in Muara Karang Coastal Waters, Jakarta Bay. Proceeding ITB, Vol. 31, No. 1. 